\section{REMISSION OF CLINICAL SIGNS OF ADULT-ONSET GENERALIZED DEMODICOSIS AFTER TREATMENT FOR CONCURRENT BABESIOSIS AND/OR GRANULOCYTIC EHRLICHIOSIS IN DOGS}

\author{
TARELLO W.*
}

Sir,

Demodicosis is a severe parasitic cutaneous disease of dogs caused by the uncontrolled proliferation of demodectic mites belonging to the genus Demodex sp. (Acari: Prostigmata) (Craig, 2003). Concomitant factors potentially immuno-suppressive such as hypothyroidism (Saridomichelakis et al., 1999), diabetes mellitus and chemotherapy (Duclos et al., 1994) have been recorded. Therapeutic responses of systemic adult-onset

* DVM, MRCVS, Studio Veterinario Spina, C.P. 1644, 06129 Perugia, Italy. Tel.: 003907550522 04. E-mail: wtarello@yahoo.it demodicosis to acaricide treatment alone (amitraz, ivermectin, milbemycin) may be incomplete or refractory (Medleau et al., 1996; Fondati, 1996) unless underlying predisposing factors and concomitant immunosuppressive diseases have been identified and removed (Craig, 2003).

Presence of babesiosis and/or ehrlichiosis and response to specific therapies was retrospectively analyzed in 12 dogs diagnosed with adult-onset generalized demodicosis (Medleau et al., 1996) resistant to standard treatments or relapsed after prior anti-parasitic therapies (Table I).

11 cases of babesiosis and eight cases of canine granulocytic ehrlichiosis (CGE) (Tarello, 2003b), were identified through microscopic examination of Wright-stained blood smears. Treatments included the administration of imidocarb dipropionate (Carbesia ${ }^{\circledR}$, Shering-Plough Animal Health, $1 \mathrm{ml} / 25 \mathrm{~kg}$, once a week, for four weeks) in dogs diagnosed with babesiosis, and of doxycycline (Ronaxan $^{\circledR}$, Merial, $10 \mathrm{mg} / \mathrm{kg} /$ day, 21-42 days) at antiehrlichial dosages in dogs diagnosed with CGE. Physi-

\begin{tabular}{|c|c|c|c|c|c|}
\hline Dog & Sex, age, breed & $\begin{array}{l}\text { Previous } \\
\text { treatments }\end{array}$ & $\begin{array}{l}\text { Clinical symptoms } \\
\text { \& signs }\end{array}$ & $\begin{array}{l}\text { Blood smear's } \\
\text { results }\end{array}$ & $\begin{array}{l}\text { Therapy } \\
\text { outcomes* }\end{array}$ \\
\hline 1 & $\begin{array}{l}\text { M, 1.1/2 yr, Pointer } \\
\text { Italy (1996) }\end{array}$ & $\begin{array}{l}\text { Amitraz, Ivermectin } \\
\text { ( no benefit) }\end{array}$ & $\begin{array}{l}\text { Whole body lesions, } \\
\text { pododemodicosis; } \\
\text { anorexia, lethargy } \\
\text { conjunctivitis \& fever }\end{array}$ & $\begin{array}{l}\text { Babesiosis }=+ \\
\mathrm{CGE}=++\end{array}$ & $\begin{array}{l}\text { Slow recovery } \\
\text { within } 9 \text { weeks }\end{array}$ \\
\hline 2 & $\begin{array}{l}\text { F, } 2 \text { yrs, Pointer } \\
\text { Italy (1997) }\end{array}$ & Amitraz (no benefit) & $\begin{array}{l}\text { Whole body lesions, } \\
\text { pododemodicosis } \\
\text { lethargy \& blepharitis } \\
\text { (conjunctivitis) }\end{array}$ & $\begin{array}{l}\text { Babesiosis }=++ \\
\mathrm{CGE}=++\end{array}$ & $\begin{array}{l}\text { Slow recovery } \\
\text { within } 8 \text { weeks }\end{array}$ \\
\hline 3 & $\begin{array}{l}\text { M, } 2 \text { yrs, Blood-hound } \\
\text { Italy (1999) }\end{array}$ & Ivermectin (no benefit & $\begin{array}{l}\text { Multiple lesions ( } 7 \text { ) } \\
\text { on head, neck and } \\
\text { thorax, lymph-adeno- } \\
\text { megaly and fever }\end{array}$ & Babesiosis $=+++$ & $\begin{array}{l}\text { Fast recovery } \\
\text { within } 3 \text { weeks }\end{array}$ \\
\hline 4 & $\begin{array}{l}\text { M, 1.1/4 yr, Am. Pitt Bull } \\
\text { Saudi Arabia (2002) }\end{array}$ & $\begin{array}{l}\text { Amitraz (partial benefit } \\
\text { followed by relapse) }\end{array}$ & $\begin{array}{l}\text { Multiple lesions (5) on } \\
\text { neck, thorax and fore } \\
\text { flimbs; conjunctivitis, } \\
\text { poor appetite }\end{array}$ & Babesiosis $=+$ & $\begin{array}{l}\text { Fast recovery } \\
\text { within } 4 \text { weeks }\end{array}$ \\
\hline 5 & $\begin{array}{l}\text { F, } 1.1 / 2 \text { yr, Ger. Shepherd } \\
\text { Saudi Arabia (2002) }\end{array}$ & $\begin{array}{l}\text { Fipronil, Amitraz, } \\
\text { Ivermectin ( } \text { no benefit) }\end{array}$ & $\begin{array}{l}\text { Multiple lesions (11) on } \\
\text { neck, thorax and limbs; } \\
\text { fever and conjunctivitis }\end{array}$ & $\begin{array}{l}\text { Babesiosis }=++ \\
\text { CGE }=++++\end{array}$ & $\begin{array}{l}\text { Fast recovery } \\
\text { within } 7 \text { weeks }\end{array}$ \\
\hline 6 & $\begin{array}{l}\mathrm{F}, 1.3 / 4 \mathrm{yr} \text {, Golden retriever } \\
\text { Saudi Arabia (2002) }\end{array}$ & $\begin{array}{l}\text { Fipronil, Amitraz, } \\
\text { Ivermectin }\end{array}$ & $\begin{array}{l}\text { Multiple lesions on four } \\
\text { limbs; lethargy and } \\
\text { limping }\end{array}$ & $\begin{array}{l}\text { Babesiosis }=+ \\
\text { CGE }=++++\end{array}$ & $\begin{array}{l}\text { Slow recovery } \\
\text { within } 9 \text { weeks }\end{array}$ \\
\hline 7 & $\begin{array}{l}\text { F, } 3 \text { yrs, Belg. Shepherd } \\
\text { Saudi Arabia (2002) }\end{array}$ & Amitraz & $\begin{array}{l}\text { Multiple lesions (8) on } \\
\text { thorax and legs; } \\
\text { Conjunctivitis }\end{array}$ & $\begin{array}{l}\text { Babesiosis }=++ \\
\mathrm{CGE}=++\end{array}$ & $\begin{array}{l}\text { Fast recovery } \\
\text { within } 4 \text { weeks }\end{array}$ \\
\hline 8 & $\begin{array}{l}\text { M, } 4 \text { yrs, Belg. Shepherd } \\
\text { Saudi Arabia (2002) }\end{array}$ & Amitraz & $\begin{array}{l}\text { Facial area and multiple } \\
\text { fore-feet lesions; } \\
\text { conjunctivitis, limping } \\
\text { and fever }\end{array}$ & $\begin{array}{l}\text { Babesiosis }=+ \\
\mathrm{CGE}=++\end{array}$ & $\begin{array}{l}\text { Fast recovery } \\
\text { within } 4 \text { weeks }\end{array}$ \\
\hline
\end{tabular}




\begin{tabular}{|c|c|c|c|c|c|}
\hline Dog & Sex, age, breed & $\begin{array}{l}\text { Previous } \\
\text { treatments }\end{array}$ & $\begin{array}{c}\text { Clinical symptoms } \\
\text { \& signs }\end{array}$ & $\begin{array}{l}\text { Blood smear's } \\
\text { results }\end{array}$ & $\begin{array}{l}\text { Therapy } \\
\text { outcomes* }\end{array}$ \\
\hline 9 & $\begin{array}{l}\text { M, } 5 \text { yrs, Germ. Shepherd } \\
\text { Saudi Arabia (2002) }\end{array}$ & Ivermectin, Fipronil & $\begin{array}{l}\text { Facial area and multiple } \\
\text { fore-feet lesions; fever, } \\
\text { vomiting, lethargy, } \\
\text { conjunctivitis }\end{array}$ & $\begin{array}{l}\text { Babesiosis }=+ \\
\mathrm{CGE}=++\end{array}$ & $\begin{array}{l}\text { Fast recovery } \\
\text { within } 5 \text { weeks }\end{array}$ \\
\hline 10 & $\begin{array}{l}\text { M, } 3 \text { yrs, Belg. Shepherd } \\
\text { Saudi Arabia (2002) }\end{array}$ & Amitraz, Milbemycin & $\begin{array}{l}\text { Pododemodicosis on } \\
4 \text { feet; fever and } \\
\text { limping }\end{array}$ & $\mathrm{CGE}=+++$ & $\begin{array}{l}\text { Slow recovery } \\
\text { within } 9 \text { weeks }\end{array}$ \\
\hline 11 & $\begin{array}{l}\text { M, 1.3/4 yr, Am. Pitt Bull } \\
\text { Kuwait (2003) }\end{array}$ & Ivermectin & $\begin{array}{l}\text { Pododemodicosis on } \\
4 \text { feet; limping and } \\
\text { bleeding from feet; } \\
\text { lymph-adenomegaly }\end{array}$ & Babesiosis $=++$ & $\begin{array}{l}\text { Fast recovery } \\
\text { within } 7 \text { weeks }\end{array}$ \\
\hline 12 & $\begin{array}{l}\text { F, 1.1/2 yr, Pug-dog } \\
\text { Thailand (2004) }\end{array}$ & $\begin{array}{l}\text { Antibiotics, vitamins, } \\
\text { Ivermectin ( } n o \text { benefit) }\end{array}$ & $\begin{array}{l}\text { Multiple lesions (12) } \\
\text { on whole body; } \\
\text { pruritus, poor appetite, } \\
\text { lethargy, limping }\end{array}$ & Babesiosis $=++$ & $\begin{array}{l}\text { Fast recovery } \\
\text { within } 7 \text { weeks }\end{array}$ \\
\hline
\end{tabular}

* Babesiosis was treated with imidocarb dipropionate (four injections, one week apart). CGE was treated with doxycycline (os., 21-42 days at $10 \mathrm{mg} / \mathrm{kg} /$ day).

Infected red (babesiosis) and white (CGE) blood cells: (+): less than $0.03 \%$; (++): from 0.03 to $0.3 \%$; (+++): from 0.3 to $3 \%$; (++++): more than $3 \%$

Table I. - Signalment, history, clinical findings and results of laboratory tests and therapies in 12 dogs with generalized demodicosis from Italy, Saudi Arabia, Kuwait and Thailand.

cal controls were performed weekly until clinical resolution. Each dog was submitted to a 6-month period of follow-up.

Cutaneous lesions due to Demodex infestation disappeared within three-nine weeks (Table I), together with general signs evocative of babesiosis and CGE, such as anorexia, lethargy, vomiting and fever (Tarello, 2003a, 2003b). No relapse was seen in dogs thus treated during a 6-month period of follow-up. Microscopic examination of skin scrapings was not performed after the end of therapy since dogs appeared clinically cured and also because Demodex mites are always present, to some extent, in the skin of normal dogs.

In blood smears of controls examined after therapy Babesia and granulocytic Ebrlichia agents resulted absent (in case $\mathrm{n}^{\circ} 3,4,7,8,9,11$ and 12) or sharply (80 to $95 \%$ ) decreased (in case $n^{\circ} 1,2,5,6$ and 10). Tick-borne parasites such as Babesia (Purvis, 1977) and Ebrlichia spp. (Collett et al., 1987) are claimed to be immunosuppressive agents. Therefore it should not be controversial to note that 12 canine cases diagnosed with concomitant babesiosis $(n=11)$ and granulocytic ehrlichiosis $(n=8)$ found complete clinical cure following specific therapies against these agents (Table I). It is acknowledged that in the course of conditioned illness the eradication of concurrent pathogens can help towards remission and prevents recurrencies (Tarello, 2002). Infective agents such as leishmaniosis are known to exacerbate canine demodicosis (Mozos et al., 1999). Moreover, clinical cure of generalized demodicosis has been achieved in the past through the elimination of underlying factors (Hillier \& Desh, 2002). General signs evocative of babesiosis and ehrlichiosis ceased concomitantly with the administration of their specific therapies and prior or simultaneously with the progressive disappearance of demodectic lesions.

Babesiosis and granulocytic ehrlichiosis should be included in the differential diagnosis of factors influencing adult-onset generalized canine demodicosis and their eradication should be considered a pre-requisite for an effective treatment.

\section{REFERENCES}

Craig M. Demodicosis, in: BSAVA Manual of small animal dermatology. Foster A.P. \& Foil C.S. (eds). BSAVA, Gloucester, 2003, 153-158.

Collett M.G., Doyle A.S., Reyners F., Kruse T. \& Fabian B. Fatal disseminated cryptococcosis and concurrent ehrlichiosis in a dog. Journal of South African Veterinary Association, 1987, 58, 197-202.

Duclos D.D., JefFers J.G. \& Shanley K.J. Prognosis for treatment of adult-onset demodicosis in dogs: 34 cases (19791990). Journal of American Veterinary Medical Association, 1994, 204, 616-619. 
FONDATI A. Efficacy of daily oral ivermectin in the treatment of 10 cases of generalized demodicosis in adult dogs. Veterinary Dermatology, 1996, 7, 99-104.

Hillier A. \& Desh C.E. Large-bodied Demodex mite infestation in four dogs. Journal of American Veterinary Medical Association 2002, 220, 623-627.

Medleau L., Ristic Z. \& McCelveen D.R. Daily ivermectin for treatment of generalized demodicosis in dogs. Veterinary Dermatology, 1996, 7, 209-212.

Mozos E., Perez J., Day M.J., Lucena R. \& Ginel P.J. Leishmaniosis and generalized demodicosis in three dogs: a clinicopathological and immunohistochemical study. Journal of Comparative Pathology 1999, 120, 257-268.

PURvis A.C. Immunodepression in Babesia microti infections. Parasitology, 1977, 75, 197-205.

Saridomichelakis M., Koutinas A., Papadogiannakis E., PapaZachariadou M., Liapi M. \& Trakas D. Adult-onset demodicosis in two dogs due to Demodex canis and a shorttailed demodectic mite. Journal of Small Animal Practice, 1999, 40, 529-532.

Tarello W. Cutaneous lesions in dogs with Dirofilaria (Nochtiella) repens infestation and concurrent tick-borne transmitted diseases. Veterinary Dermatology, 2002, 13, 267274 .

TARELlo W. Concurrent cutaneous lesions in dogs with Babesia gibsoni infection in Italy. Revue de Médecine Vétérinaire, 2003a, 154, 281-287.

TARello W. Canine granulocytic ehrlichiosis (CGE) in Italy. Acta Veterinaria Hungarica, 2003b, 51, 73-90.

Reçu le 15 juin 2007

Accepté le 20 septembre 2007

\section{Erratum}

Roy L. \& Chauve C.M. Historical review of the genus Dermanyssus Dugès, 1834 (Acari: Mesostigmata: Dermanyssidae). Parasite, 2007, 14 (2), 87-100.

The authors wish to correct an error in the published manuscript. On page 97, column 2, line 16, a confusion between two species names (D. passerinus and D. hirundinis) has been found. The sentence should read: "Moreover, according to Moss, it is most likely that D. longipes and D. hirundinis are conspecific". Authors apologize to readers for this mistake. 